\title{
Oxidative stress gene expression profile in inbred mouse after ischemia/reperfusion small bowel injury ${ }^{1}$
}

\author{
Perfil da expressão gênica do estresse oxidativo em \\ camundongos isogênicos após lesão de isquemia e reperfusão intestinal
}

\author{
Paulo Roberto Bertoletto ${ }^{\mathrm{I}}$, Adauto Tsutomu Ikejiri" ${ }^{\mathrm{II}}$, Frederico Somaio Neto ${ }^{\mathrm{II}}$, José Carlos Chaves ${ }^{\mathrm{III}}$, Roberto Teruya ${ }^{\mathrm{IV}}$, Eduardo \\ Rodrigues Bertolettov, Murched Omar Taha ${ }^{\mathrm{VI}}$, Djalma José Fagundes ${ }^{\mathrm{VI}}$
}

\begin{abstract}
IPhD, Associate Professor, Medical School, UFGD, Dourados-MS, Brazil. Responsible for intellectual and scientific content of the study, protocol design, technical procedures, acquisition and interpretation of data, statistical analysis, manuscript writing, critical revision.

"Fellow Master degree in Surgery, Postgraduate Program in Interdisciplinary Surgical Sciences, UNIFESP. Associate Professor, Medical School, UFGD, Dourados-MS, Brazil. Acquisition and interpretation of data, technical procedures, statistical analysis, manuscript writing.

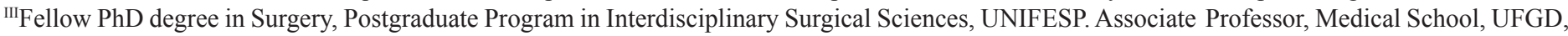
Dourados-MS, Brazil. Acquisition and interpretation of data, technical procedures, statistical analysis, manuscript writing.

${ }^{\mathrm{IV}}$ Fellow PhD degree in Surgery, Postgraduate Program in Interdisciplinary Surgical Sciences, UNIFESP. Affiliate Professor, Surgery Department, Federal University of Mato Grosso do Sul (UFMS), Campo Grande-MS, Brazil. Acquisition and interpretation of data, technical procedures, statistical analysis, manuscript writing.

${ }^{\vee}$ Graduate student, Sao Camilo University Center, Sao Paulo-SP, Brazil. Acquisition and interpretation of data, technical procedures.

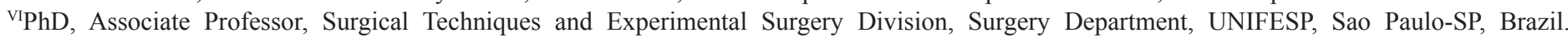
Interpretation of data, conception and design of the study, manuscript writing, critical revision.
\end{abstract}

\section{ABSTRACT}

PURPOSE: To determine the profile of gene expressions associated with oxidative stress and thereby contribute to establish parameters about the role of enzyme clusters related to the ischemia/reperfusion intestinal injury.

METHODS: Twelve male inbred mice (C57BL/6) were randomly assigned: Control Group (CG) submitted to anesthesia, laparotomy and observed by 120min; Ischemia/reperfusion Group (IRG) submitted to anesthesia, laparotomy, 60min of small bowel ischemia and $60 \mathrm{~min}$ of reperfusion. A pool of six samples was submitted to the qPCR-RT protocol (six clusters) for mouse oxidative stress and antioxidant defense pathways.

RESULTS: On the 84 genes investigated, 64 (76.2\%) had statistic significant expression and 20 (23.8\%) showed no statistical difference to the control group. From these 64 significantly expressed genes, 60 (93.7\%) were up-regulated and 04 (6.3\%) were down-regulated. From the group with no statistical significantly expression, 12 genes were up-regulated and 8 genes were down-regulated. Surprisingly, 37 (44.04\%) showed a higher than threefold up-regulation and then arbitrarily the values was considered as a very significant. Thus, 37 genes (44.04\%) were expressed very significantly up-regulated. The remained 47 (55.9\%) genes were up-regulated less than three folds (35 genes $-41.6 \%$ ) or down-regulated less than three folds (12 genes $-14.3 \%$ ).

CONCLUSION: The intestinal ischemia and reperfusion promote a global hyper-expression profile of six different clusters genes related to antioxidant defense and oxidative stress.

Key words: Oxidative Stress. Antioxidants. Gene expression. Ischemia. Reperfusion. Real-Time Polymerase Chain Reaction. Mice.

\section{RESUMO}

OBJETIVO: Determinar o perfil de expressão dos genes associados com estresse oxidativo e contribuir para estabelecer parâmetros sobre o papel das familias de enzimas relacionadas com a lesão de isquemia / reperfusão intestinal.

MÉTODOS: Doze camundongos machos isogênicos (C57BL/6) foram distribuídos aleatoriamente: Grupo Controle (CG) submetido à laparotomia anestesia, e observado por 120min; Grupo isquemia/reperfusão (IRG) submetido à anestesia, laparotomia, 60min de isquemia do intestino delgado e $60 \mathrm{~min}$ de reperfusão. Um pool dos seis camundongos de cada grupo foi submetido ao protocolo de 
qPCR-RT (seis famílias) para o estresse oxidativo e defesa antioxidante

RESULTADOS: Dos 84 genes investigados, 64 (76,2\%) tiveram expressão estatística significante e 20 (23,8\%) não apresentaram diferença estatística com o grupo controle. Dos 64 genes expressos de forma significante, 60 (93,7\%) foram hiper-expressos e 04 (6,3\%) foram hipo-expressos. Do grupo sem expressão estatisticamente significante, 12 genes foram hiper e 8 genes foram hipo-expressos. Surpreendentemente, 37 (44,04\%) apresentaram expressão três maior que o limiar de normalidade e arbitrariamente os valores foram considerados como altamente significantes. Assim, 37 genes $(44,04 \%)$ foram hiper-expressos de modo muito significante. Nos demais, $47(55,9 \%)$ dos genes foram hiper-expressos menos de três vezes (35 genes - 41,6\%) ou hipo-expressos menos de três vezes(12 genes $-14,3 \%)$.

CONCLUSÃO: A isquemia e reperfusão intestinal promoveu um perfil de hiper-expressão global das seis familias de genes relacionados com estresse oxidativo antioxidante e defesa antioxidante.

Descritores: Estresse Oxidativo. Antioxidantes. Expressão Gênica. Isquemia. Reperfusão. Reação em Cadeia da Polimerase em Tempo $\underline{\text { Real. Camundongos. }}$

\section{Introduction}

The oxygen is a critical substrate in the alleviation of hypoxia, anoxia, and ischemia, but paradoxically, it also functions as a deleterious metabolite during the reperfusion of previously ischemic tissues ${ }^{1-3}$. Ischemia reperfusion injury (IRI) is often seen in organ transplants, major organ resections and in shock ${ }^{4}$.

Reactive oxygen species (ROS) generated during the reperfusion phase overwhelms the scavenging capacities of antioxidant enzymes, and result in oxidative damage ${ }^{4,5}$. The oxidative stress occurs early (i.e., minutes) after reoxygenation and will inflict further damage to numerous cellular elements such as mitochondria, proteins, nucleic acids and cellular membranes ${ }^{4,5}$. The stress may lead either to immediate cell death (necrosis), controlled cell death (apoptosis) or trigger changes of the cell phenotype in response to the injury ${ }^{6,7}$.

The published literature to evaluate the IRI is focused on morphological and biochemical changes involved in the cascade of oxidative stress which, either directly by ROS or through lipoperoxidation products, may initiate the activation of specific transcription factors and expression of appropriate target genes as adaptation in response to the damage ${ }^{3-6}$. Knowledge of the interrelationships of these genes must be useful as potential targets for therapeutic intervention against IRI ${ }^{8,9}$.

This research attempts to bring into the spotlight some pertinent developments regarding to the gene expression associated to the oxidative stress on the ischemia injury of small bowel. This hypothesis was tested in the present study using array technology for quantitative real-time polymerase chain reaction ${ }^{10}$ (qRT-PCR) which provides a powerful tool to simultaneously analyze expression of these specific genes in intestinal tissue.

The objective was to determine the profile of gene expressions associated with oxidative stress and thereby contributes to establish parameters about the role of enzyme clusters related to the ischemia/reperfusion intestinal injury.

\section{Methods}

The experimental protocol (\#1379/08) was approved by the Ethics Committee of the Federal University of Sao Paulo (UNIFESP), Brazil. The study was designed as a randomized controlled trial with a blinded assessment of the outcome using inbred mice (C57BL/6).

Twelve male inbred mice - C57BL/6 (Center for the Development of Experimental Models for Medicine and Biology - CEDEME/UNIFESP) that weighed 35 to $40 \mathrm{~g}$ were housed under temperature and light controlled environmental conditions with a 12 hours light-dark cycle. The animals had free access to water and standard pellet chow until six hours prior to the surgical procedures. All procedures were conducted in the laboratories of Experimental Surgery, Department of Surgery at Federal University of Grande Dourados (UFGD), Brazil. The animals were randomly assigned to one of two groups: Control Group (CG) submitted to anesthesia, laparotomy and observed by $120 \mathrm{~min}$; Ischemia/reperfusion Group (IRG) submitted to anesthesia, laparotomy, 60min of small bowel ischemia and $60 \mathrm{~min}$ of reperfusion.

The animals received an intramuscular combination of $44 \mathrm{mg} / \mathrm{kg}$ of ketamine, $2.5 \mathrm{mg} / \mathrm{kg}$ of xylazine and $0.75 \mathrm{mg} / \mathrm{kg}$ of acepromazine. Body temperature was maintained at $37.8^{\circ} \mathrm{C}$ using a homeothermic soft blanket. After the samples were collected, the animals were dead by beheading.

Under aseptic conditions and using a magnification device (4x), all 12 animals underwent a midline laparotomy. In the IRG $(n=6)$ the superior mesenteric artery was carefully dissected and then occluded by a microvascular clamp during 60min. Ischemia was confirmed by observing the pale appearance of the clamped 
small bowel and absent of beats in the mesenteric branches artery. The surgical wounds remained covered with wet gauze wrappings to minimize evaporative loss. After $60 \mathrm{~min}$ the clamp was removed, reperfusion was evaluated based on immediate color recovery and artery beats. Following 60min of reperfusion there was a collected sample $(3 \mathrm{~cm}$ each) of small bowel $20 \mathrm{~cm}$ far from the duodenojejunal flexure. In the $\mathrm{CG}(\mathrm{n}=6)$ was performed the anesthesia, laparotomy, superior mesenteric artery dissection without occlusion, and following the $120 \mathrm{~min}$ was a collected sample $(3 \mathrm{~cm})$ of small bowel. All the samples were longitudinally open, gently washed in saline solution and less than one and half minute was involved in aluminum sheet and harvested in liquid nitrogen.

$\mathrm{RT}^{2}$ Profiler ${ }^{\mathrm{TM}}$ PCR array from SA Biosciences (Frederick, Maryland; cat \# PAMM-065) was performed for mouse oxidative stress and antioxidant defense pathways according to manufacturer's protocol. Briefly, total RNA was extracted from CG and IRG small bowel tissues using Trizol reagent (Life Technologies, Grand Island, NY, USA) and step crossed purified (Rneasy MiniKit Qiagen, Co - USA). The concentration of total RNA samples was determined by spectrophotometry and quality assessed using the same analysis on agarose gel $2 \%$. One microgram of total RNA was used to make first strand complementary DNA (cDNA) using RT2 First Strand Kit (SABiosciences). Equal amount of cDNA was mixed with Master Mix - SYBR Green Company SA Biosciences (Qiagen, Co) and aliquoted to each well of the PCR array plate containing the pre-dispensed gene-specific primer sets, and performed PCR according to manufacturer's instruction. The PCR was done in 96 well plates with 84 genes related to oxidative stress, five housekeeping genes (Actin B, Gapdh, Hsp90ab1, Hprt1, Gusb) used for normalizing the PCR array data, and one negative control for genomic DNA contamination, a primer set that specifically detects non-transcribed, repetitive genomic DNA with a high level of sensitivity, and three wells of reverse transcription controls (RTC) to verify the efficiency of the RT reaction with a qPCR assay that specifically detects template synthesized from the first strand synthesis kit's built-in external RNA control. The replicate positive PCR controls (PPC) were also used to check the efficiency of the polymerase chain reaction itself. These elements use a pre-dispensed artificial DNA sequence and the primer set that detects it. The two sets of replicate control wells (RTC and PPC) also test for inter-well and intra-plate consistency. The instrument's software (MxPro Equipment Real Time Systems Stratagene - GE, Co) calculates the threshold cycle $(\mathrm{Ct})$ values for all the genes in the array. Finally, it calculates fold changes in gene expression for pair wise comparison using the $\Delta \Delta \mathrm{Ct}$ method from the raw threshold cycle data. This method used in our study to determine the relative expression levels of genes of interest for each sample are contained in the spreadsheet itself for analysis of plates of sheet PCR Array Data Analysis v3.3 (SA Biosciences Qiagen, Co).

\section{Statistical analysis}

The analysis of gene expression by real-time PCR used in this work represents a relative quantification of genes of interest. To support the analysis 06 endogenous controls were part of the PCR reactions array for each of the samples tested, genes whose expression was used do not present a statistically significant variation between samples. The control samples for each experimental group were used as reference baseline. The results were transformed into $\log 2$ scale for the calculation of averages and standard errors and for statistical analysis. FoldChange $\left[2^{\wedge}(-\right.$ Delta Delta $\left.\mathrm{Ct})\right]$ is the normalized gene expression $\left[2^{\wedge}(-\right.$ Delta $\left.\mathrm{Ct})\right]$ in the Test Sample divided the normalized gene expression $\left[2^{\wedge}(-\right.$ Delta $\left.\mathrm{Ct})\right]$ in the Control Sample. Fold-Regulation represents fold-change results in a biologically meaningful way. It was considered that fold-change values greater than one indicates a positive- or an up-regulation, and the fold-regulation is equal to the fold-change. The $\mathrm{p}$ values are calculated based on a Student's t-test of the replicate $2^{\wedge}(-$ Delta $\mathrm{Ct})$ values for each gene in the control group and treatment groups. $\mathrm{P}$ values less than 0.05 was considered significant in all experiments and indicated by symbols.

\section{Results}

Given the 84 genes related to oxidative stress and antioxidant defense in the inbred mice (C57BL/6), $64(76.2 \%)$ genes had statistic significant expression and 20 (23.8\%) showed no statistical difference to the control group. From these 64 significantly expressed genes, 60 (93.7\%) were up-regulated and $04(6.3 \%)$ were down-regulated. From the group with no statistical significantly expression, 12 genes were up-regulated and 8 genes were down-regulated. On the 84 genes investigated, 37 (44.04\%) showed a higher than threefold up-regulation. The gene bank, symbol abbreviation (alphabetical order), description of genes, the fold up or down-regulation, and the $p$ value were depicted on the sequence of Tables 1, 2 and 3. In the Figure 1 the scatter plot allows the visualization of up and down fold-regulation between the test sample and control in the 84 genes expression investigated. Six major functional gene clusters allowed by qRTPCR kit were subjected to hierarchical clustering analysis using 
the $\Delta \Delta \mathrm{Ct}$ method from the raw threshold cycle data: glutathione peroxidase (ten genes), antioxidants peroxiredoxin (eight genes), antioxidants peroxidases (16 genes), reactive oxygen species (ROS), superoxide metabolism (16 genes), oxidative stress (22 genes) and genes involved in oxygen transporters metabolism (12 genes).

With regard to genes related to glutathione peroxidases (GPx) the expression of $70 \%$ showed fold up-regulation; genes involved with the antioxidants peroxiredoxin (TPx), 75\% showed significant fold up-regulation; genes involved with the antioxidants peroxidases, $87.5 \%$ showed significant fold up-regulation; genes involved in reactive oxygen species (ROS) and superoxide metabolism, 93.7\% showed significant fold up-regulation; genes involved in oxidative stress responsive metabolism, 84.6\% showed significant fold up-regulation; genes involved in oxygen transporters metabolism, 91.7\% showed significant fold upregulation.

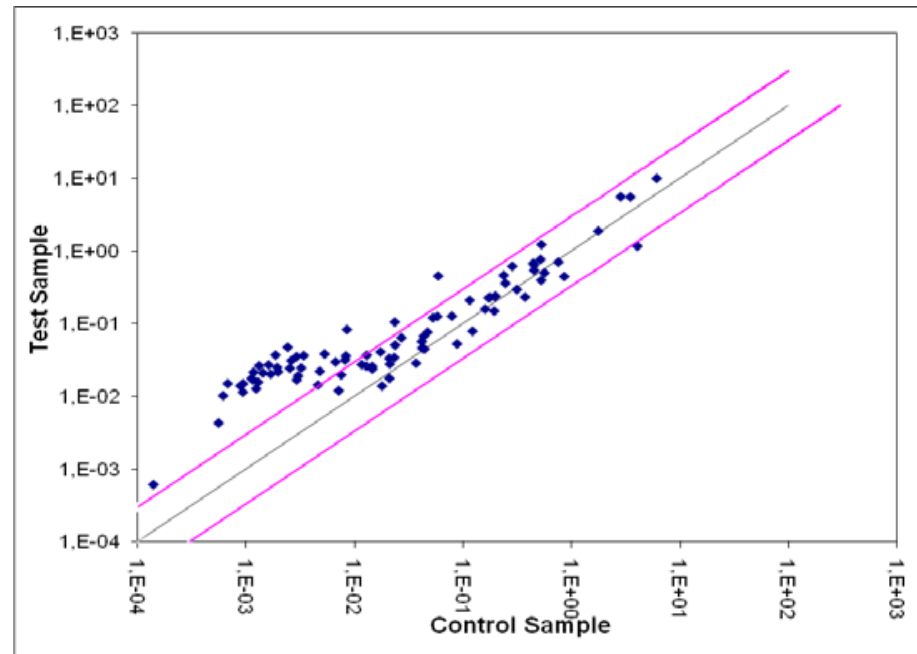

FIGURE 1 - Scatter plot allows the visualization of up and down foldregulation of all gene expression investigated. The black line indicates fold changes $\left[\left(2^{\wedge}\left(-D C_{t}\right)\right]\right.$ of 1 . The pink lines indicate the threefoldchange in gene expression threshold.
TABLE 1 - Alphabetical sequence of genes investigated and the fold up (+) or down (-) regulation (Bold=up-regulation/ threefold). (Student's t-test). $(*=$ significant value $\mathrm{p}<0.05)$.

\begin{tabular}{|c|c|c|c|c|c|}
\hline$\#$ & Gene Bank & Symbol & Gene description & $\begin{array}{c}\text { Fold } \\
\text { Up/down }\end{array}$ & $p$ value \\
\hline 1 & NM_013930 & Aass & $\begin{array}{c}\text { Aminoadipate- } \\
\text { semialdehyde synthase }\end{array}$ & +19.64 & 0.000001 * \\
\hline 2 & NM_028717 & Als2 & $\begin{array}{l}\text { Amyotrophic lateral } \\
\text { sclerosis } 2 \text { homolog }\end{array}$ & +1.47 & 0.001659 * \\
\hline 3 & NM_007462 & $\mathrm{Apc}$ & $\begin{array}{l}\text { Adenomatosis polyposis } \\
\text { coli }\end{array}$ & -1.07 & 0.550495 \\
\hline 4 & NM_009696 & Apoe & Apolipoprotein E & +1.94 & 0.002533 * \\
\hline 5 & NM_009702 & Aqr & Aquarius & +2.35 & $0.000257^{*}$ \\
\hline 6 & NM_019864 & Atr & $\begin{array}{c}\text { Ataxia telangiectasia and } \\
\operatorname{rad} 3 \text { related }\end{array}$ & +2.84 & 0.000036 * \\
\hline 7 & NM_009804 & Cat & Catalase & +2.31 & $0.000234 *$ \\
\hline 8 & NM_016892 & Ccs & $\begin{array}{l}\text { Copper chaperone/ } \\
\text { superoxide dismutase }\end{array}$ & +2.37 & 0.124457 \\
\hline 9 & NM_001081339 & Xirp1 & $\begin{array}{l}\text { Xin actin-binding repeat } \\
\text { containing } 1\end{array}$ & +15.85 & 0.000232 * \\
\hline 10 & NM_007798 & $\mathrm{Ctsb}$ & Cathepsin B & +1.46 & 0.084244 \\
\hline 11 & NM_007806 & Cyba & $\begin{array}{l}\text { Cytochrome b-245. alpha } \\
\text { polypeptide }\end{array}$ & -1.55 & 0.077515 \\
\hline 12 & NM_030206 & Cygb & Cytoglobin & +6.37 & $0.001317 *$ \\
\hline 13 & NM_001039520 & Dnm2 & Dynamin 2 & -1.34 & 0.095871 \\
\hline 14 & XM_130483 & Duox 1 & Dual oxidase 1 & +12.08 & $0.000466^{*}$ \\
\hline 15 & NM_153068 & Ehd2 & EH-domain containing 2 & +12.05 & $0.000047^{*}$ \\
\hline 16 & NM_007946 & Epx & Eosinophil peroxidase & $+\mathbf{1 6 . 8 5}$ & 0.002598 * \\
\hline 17 & NM_007949 & Ercc2 & $\begin{array}{l}\text { Excision repair cross- } \\
\text { complementing } 2\end{array}$ & +4.34 & $0.001642 *$ \\
\hline 18 & NM_001081221 & Ercc6 & $\begin{array}{l}\text { Excision repair cross- } \\
\text { complementing } 6\end{array}$ & +2.17 & $0.003671^{*}$ \\
\hline 19 & NM_007985 & Fancc & $\begin{array}{l}\text { Fanconi anemia. } \\
\text { complementation C }\end{array}$ & +7.25 & 0.000015 * \\
\hline 20 & NM_018881 & Fmo2 & $\begin{array}{l}\text { Flavin containing } \\
\text { monooxygenase } 2\end{array}$ & +1.60 & 0.019633 * \\
\hline 21 & NM_021356 & Gab1 & $\begin{array}{l}\text { Growth factor receptor } \\
\text { bound protein } 2\end{array}$ & +1.10 & 0.197265 \\
\hline 22 & NM_008160 & Gpx1 & Glutathione peroxidase 1 & +1.61 & $0.001431 *$ \\
\hline 23 & NM_030677 & Gpx2 & Glutathione peroxidase 2 & -1.30 & 0.208667 \\
\hline 24 & NM_008161 & Gpx3 & Glutathione peroxidase 3 & -1.18 & 0.226815 \\
\hline 25 & NM_008162 & Gpx4 & Glutathione peroxidase 4 & -1.93 & $0.000234 *$ \\
\hline 26 & NM_010343 & Gpx5 & Glutathione peroxidase 5 & +4.42 & 0.001774 * \\
\hline 27 & NM_145451 & Gpx6 & Glutathione peroxidase 6 & +12.28 & 0.000015* \\
\hline 28 & NM_024198 & Gpx7 & Glutathione peroxidase 7 & $+\mathbf{1 6 . 0 1}$ & $0.000362 *$ \\
\hline 29 & NM_027127 & Gpx8 & $\begin{array}{c}\text { Glutathione peroxidase } 8 \\
\text { (putative) }\end{array}$ & +1.78 & 0.072334 \\
\hline 30 & NM_010344 & Gsr & Glutathione reductase & +1.36 & 0.149896 \\
\hline 31 & NM_029555 & Gstk1 & $\begin{array}{c}\text { Glutathione S-transferase } \\
\text { kappa } 1\end{array}$ & +1.32 & $0.002691 *$ \\
\hline
\end{tabular}


TABLE 2 - Alphabetical sequence of genes investigated and the fold up (+) or down (-) regulation (Bold=up-regulation/ threefold). (Student's t-test). $(*=$ significant value $\mathrm{p}<0.05)$.

\begin{tabular}{|c|c|c|c|c|c|}
\hline \# & Gene Bank & Symbol & Gene description & $\begin{array}{c}\text { Fold } \\
\text { Up/down }\end{array}$ & $p$ value \\
\hline 32 & NM_175000 & Hbq1 & Hemoglobin. theta 1 & $+\mathbf{1 8 . 3 9}$ & $0.000126 *$ \\
\hline 33 & NM_010497 & Idh1 & $\begin{array}{c}\text { Isocitrate } \\
\text { dehydrogenase } 1 \\
\text { (NADP }+ \text { ). }\end{array}$ & -1.13 & 0.266264 \\
\hline 34 & NM_026298 & Ift 172 & $\begin{array}{l}\text { Intraflagellar } \\
\text { transport } 172 \\
\text { homolog }\end{array}$ & +7.68 & $0.000029 *$ \\
\hline 35 & NM_001009940 & Il19 & Interleukin 19 & +12.93 & 0.000010 * \\
\hline 36 & NM_016971 & Il22 & Interleukin 22 & +19.90 & 0.000083 * \\
\hline 37 & NM_010628 & Kif9 & $\begin{array}{l}\text { Kinesin family } \\
\text { member } 9\end{array}$ & +12.24 & 0.000681 * \\
\hline 38 & NM_080420 & Lpo & Lactoperoxidase & +22.32 & 0.000020 * \\
\hline 39 & NM_013593 & $\mathrm{Mb}$ & Myoglobin & $+\mathbf{1 0 . 3 1}$ & $0.000024 *$ \\
\hline 40 & NM_010824 & Mpo & Myeloperoxidase & $+\mathbf{1 1 . 9 3}$ & $0.000008 *$ \\
\hline 41 & NM_145143 & Mpp4 & $\begin{array}{c}\text { Membrane protein. } \\
\text { palmitoylated } 4\end{array}$ & +7.77 & 0.000001 * \\
\hline 42 & NM_010877 & Ncf2 & $\begin{array}{c}\text { Neutrophil cytosolic } \\
\text { factor } 2\end{array}$ & +4.48 & $0.000018 *$ \\
\hline 43 & NM_022414 & $\mathrm{Ngb}$ & Neuroglobin & $+\mathbf{1 1 . 0 8}$ & 0.000386 * \\
\hline 44 & NM_010927 & Nos2 & $\begin{array}{l}\text { Nitric oxide synthase } \\
\text { 2. inducible }\end{array}$ & +4.64 & $0.000117 *$ \\
\hline 45 & NM_172203 & Nox1 & NADPH oxidase 1 & +14.76 & 0.000077 * \\
\hline 46 & NM_015760 & Nox4 & NADPH oxidase 4 & +12.26 & $0.000005 *$ \\
\hline 47 & NM_172204 & Noxa1 & $\begin{array}{l}\text { NADPH oxidase } \\
\text { activator } 1\end{array}$ & +3.13 & 0.000083 * \\
\hline 48 & NM_027988 & Noxo1 & $\begin{array}{l}\text { NADPH oxidase } \\
\text { organizer } 1\end{array}$ & +1.32 & 0.000177 * \\
\hline 49 & NM_008706 & Nqo1 & $\begin{array}{c}\mathrm{NAD}(\mathrm{P}) \mathrm{H} \\
\text { dehydrogenase. } \\
\text { quinone } 1\end{array}$ & +1.19 & 0.194275 \\
\hline 50 & NM_172527 & Nudt15 & Nudix type motif 15 & +9.77 & $0.000018 *$ \\
\hline 51 & NM_008750 & Nxn & Nucleoredoxin & +2.03 & $0.002268 *$ \\
\hline 52 & NM_020569 & Park7 & Parkinson disease 7 & +1.82 & $0.001012 *$ \\
\hline 53 & NM_133819 & Ppp1r15b & $\begin{array}{l}\text { Protein phosphatase } \\
\text { 1. Subunit } 15 \mathrm{~b}\end{array}$ & -1.01 & 0.962143 \\
\hline 54 & NM_011034 & $\operatorname{Prdx} 1$ & Peroxiredoxin 1 & +1.30 & $0.031985 *$ \\
\hline 55 & NM_011563 & $\operatorname{Prdx} 2$ & Peroxiredoxin 2 & +1.47 & $0.015081 *$ \\
\hline 56 & NM_007452 & $\operatorname{Prdx} 3$ & Peroxiredoxin 3 & +1.52 & $0.030003 *$ \\
\hline 57 & NM_016764 & $\operatorname{Prdx} 4$ & Peroxiredoxin 4 & +1.21 & 0.270081 \\
\hline 58 & NM_012021 & $\operatorname{Prdx} 5$ & Peroxiredoxin 5 & -1.61 & $0.008534^{*}$ \\
\hline 59 & NM_007453 & Prdx6 & Peroxiredoxin 6 & -1.29 & $0.010835^{*}$ \\
\hline 60 & NM_177256 & Prdx6-rs1 & $\begin{array}{l}\text { Peroxiredoxin } 6 . \\
\text { related sequence } 1\end{array}$ & +1.02 & 0.848407 \\
\hline
\end{tabular}

TABLE 3 - Alphabetical sequence of genes investigated and the fold up (+) or down (-) regulation (Bold=up-regulation/ threefold). (Student's t-test). $(*=$ significant value $\mathrm{p}<0.05)$.

\begin{tabular}{|c|c|c|c|c|c|c|}
\hline$\#$ & Gene Bank & & Symbol & Gene description & $\begin{array}{c}\text { Fold } \\
\text { Up/down } \\
\end{array}$ & $p$ value \\
\hline 61 & NM_011170 & 61 & Prnp & Prion protein & +5.77 & $0.001140 *$ \\
\hline 62 & NM_011186 & 62 & Psmb5 & $\begin{array}{l}\text { Proteasome } \\
\text { subunit. beta } \\
\text { type } 5\end{array}$ & +1.20 & 0.078442 \\
\hline 63 & NM_008969 & 63 & Ptgs 1 & $\begin{array}{l}\text { Prostaglandin- } \\
\text { endoperoxide } \\
\text { synthase } 1\end{array}$ & +1.55 & $0.012124 *$ \\
\hline 64 & NM_011198 & 64 & Ptgs 2 & $\begin{array}{l}\text { Prostaglandin- } \\
\text { endoperoxide } \\
\text { synthase } 2\end{array}$ & +9.65 & 0.000003 * \\
\hline 65 & NM_009020 & 65 & Rag2 & $\begin{array}{c}\text { Recombination } \\
\text { activating gene } 2\end{array}$ & +14.60 & $0.000293 *$ \\
\hline 66 & NM_058214 & 66 & Recq14 & $\begin{array}{c}\text { RecQ protein- } \\
\text { like } 4\end{array}$ & +10.76 & $0.000121 *$ \\
\hline 67 & NM_009127 & 67 & Scd1 & $\begin{array}{c}\text { Stearoyl- } \\
\text { Coenzyme A } \\
\text { desaturase } 1\end{array}$ & +7.65 & $0.000420 *$ \\
\hline 68 & NM_173052 & 68 & Serpinb1b & $\begin{array}{c}\text { Serine (or } \\
\text { cysteine) peptidase } \\
\text { inhibitor. }\end{array}$ & +1.62 & 0.065882 \\
\hline 69 & NM_134086 & 69 & Slc38al & $\begin{array}{c}\text { Solute carrier } \\
\text { family } 38 \text {. member } \\
1\end{array}$ & +4.47 & $0.000106 *$ \\
\hline 70 & NM_027868 & 70 & Slc4la3 & $\begin{array}{c}\text { Solute carrier } \\
\text { family } 41 \text {. member } \\
3\end{array}$ & -1.29 & 0.391744 \\
\hline 71 & NM_011434 & 71 & Sod1 & $\begin{array}{c}\text { Superoxide } \\
\text { dismutase } 1 . \\
\text { soluble }\end{array}$ & +1.41 & 0.062857 \\
\hline 72 & NM_013671 & 72 & Sod2 & $\begin{array}{l}\text { Superoxide } \\
\text { dismutase } 2 . \\
\text { mitochondrial }\end{array}$ & +1.61 & $0.009249 *$ \\
\hline 73 & NM_011435 & 73 & Sod3 & $\begin{array}{l}\text { Superoxide } \\
\text { dismutase } 3 . \\
\text { extracellular }\end{array}$ & +2.62 & 0.002347 * \\
\hline 74 & NM_029688 & 74 & Srxn1 & $\begin{array}{c}\text { Sulfiredoxin } 1 \\
\text { homolog (S. } \\
\text { cerevisiae) }\end{array}$ & -1.67 & $0.000594 *$ \\
\hline 75 & NM_021883 & 75 & Tmod1 & Tropomodulin 1 & $+\mathbf{1 5 . 8 0}$ & $0.000161 *$ \\
\hline 76 & NM_009417 & 76 & Tpo & $\begin{array}{c}\text { Thyroid } \\
\text { peroxidase }\end{array}$ & +20.12 & $0.000043 *$ \\
\hline 77 & NM_023719 & 77 & Txnip & $\begin{array}{l}\text { Thioredoxin } \\
\text { interacting protein }\end{array}$ & +1.95 & $0.000260 *$ \\
\hline 78 & NM_015762 & 78 & Txnrd1 & $\begin{array}{l}\text { Thioredoxin } \\
\text { reductase } 1\end{array}$ & +1.63 & 0.058357 \\
\hline 79 & NM_013711 & 79 & Txnrd2 & $\begin{array}{l}\text { Thioredoxin } \\
\text { reductase } 2\end{array}$ & +1.68 & $0.000027 *$ \\
\hline 80 & NM_153162 & 80 & Txnrd3 & $\begin{array}{l}\text { Thioredoxin } \\
\text { reductase } 3\end{array}$ & +2.36 & $0.001705 *$ \\
\hline 81 & NM_009464 & 81 & Ucp3 & $\begin{array}{l}\text { Uncoupling } \\
\text { protein } 3\end{array}$ & $+\mathbf{1 6 . 7 0}$ & $0.000102 \%$ \\
\hline 82 & NM_011701 & 82 & Vim & Vimentin & +2.16 & $0.000155 *$ \\
\hline 83 & NM_011728 & 83 & Xpa & $\begin{array}{c}\text { Xeroderma } \\
\text { pigmentosum. }\end{array}$ & +2.14 & $0.002744 *$ \\
\hline 84 & XM_127602 & 84 & Zmynd17 & $\begin{array}{l}\text { Zinc finger. } \\
\text { MYND domain } \\
\text { containing } 17\end{array}$ & +3.87 & $0.000172 *$ \\
\hline
\end{tabular}




\section{Discussion}

Our data demonstrated the effective detection of differential expression of 84 gene transcripts which are involved in oxidative stress and antioxidant-related gene expression in ischemia/reperfusion injury of small bowel by using quantitative RT-PCR array. Surprisingly, the high values of up-regulation were unexpected findings and then arbitrarily the threshold of three folds values of up- or down-regulation of six samples pool of inbred mice of IRG in comparison to CG we considered as a very significant. Thus, 37 genes $(44.04 \%)$ were expressed very significantly up-regulated. The remaining 47 (55.9\%) genes were up-regulated less than three folds ( 35 genes $-41.6 \%$ ) or downregulated less than three folds (12 genes $-14.3 \%$ ), as compared to control small bowel sample.

Determining protein functions from genomic sequences is a challenge. The studies in literature are based in the assumption that proteins that function together in a pathway or structural complex are likely to evolve in a correlated fashion ${ }^{11}$.

The findings explored in the present study attempt to signal the possible implications of current knowledge and future lines of inquiry to elucidate this relationship. The following clusters analysis is based on the available literature on gene expression in general, since it specifically in relation to gut the reports are limited.

The glutathione and peroxiredoxin are two families of thiol peroxidases catalyze the reduction of hydroperoxides by thiols, essentially by similar mechanisms. The similarity of Gpx and Prx mechanisms and specificities should, however, not be considered indicative of a common phylogenetic ancestor; it rather is an example of convergent evolution. Just focusing on the situation in mammals, we have to encounter eight Gpx- and six Prx-type peroxidases on top of catalase, other heme peroxidases, and GSH-S-transferases doing similar jobs ${ }^{12}$.

The peroxidase activity of glutathione play the biological role to protect the organism from oxidative damage reducing lipid hydroperoxides to their corresponding alcohols and reducing free hydrogen peroxide to water. It is expressed in nearly every mammalian cell. There are several isozymes encoded by eight different genes isoforms, which vary in cellular location and substrate specificity.

In our results we highlight the over expression of Gpx5, Gpx6 and Gpx7. Gpx7 is unrelated to the other isoforms but has high intensity expression profile in human tissue with highconfidence $(p<0.04)$ mainly in smooth muscle ${ }^{13}$. The integrity of the muscle layer directly affects bowel motility, although it has greater resistance to necrosis and apoptosis in ischemic conditions than the mucosal layer ${ }^{13-16}$. The up-regulation of Gpx7 may be a promising factor in further research to clarify their involvement in the whole antioxidant process and as a monitor of therapeutic procedures. Moreover, the up-regulation of other isoforms of the cluster of glutathione can be investigated with the same purpose.

The peroxiredoxin (Prdx) represents an important emerging family of sulfhydryl-linked antioxidant proteins, apparently ubiquitously present in all known organisms. The antioxidant function of the peroxiredoxin complements that of other enzymic and non-enzymic systems within the cell. In addition, there is increasing evidence that the peroxiredoxin play a role in cell signaling, by controlling and/or sensing hydrogen peroxide and peroxynitrite levels ${ }^{17}$.

On the cluster of 08 genes involved with the Prdx genes $06(75 \%)$ of them were up-expressed. However, Ehd 2 were significantly expressed over than threefold. This gene, as the Gpx7, was report as of high intensity expression profile in human tissue with high-confidence $(\mathrm{p}<0.04)$ mainly in smooth muscle ${ }^{18}$. The over expression of the peroxiredoxin cluster genes and their relationship with the antioxidant pathway is a challenging task.

Peroxidases are a large family of catalyst enzymes. For many of these enzymes the optimal substrate is hydrogen peroxide, but others are more active with organic hydroperoxides such as lipid peroxides. Peroxidases can contain a heme cofactor in their active sites, or redox- active cysteine or selenocysteine residues. While the exact mechanisms have yet to be elucidated, peroxidases are known to play a part in modulation of oxidative stress ${ }^{19}$. On the 16 peroxidases allowed by the kit of PCR array 04 (25\%) were up regulated less than threefold (Cat, Ctsb, Ptgs1, Serpinb1b) and $10(62.5 \%)$ showed up regulation over than threefold (Aass, Duox1, Epx, Kif9, Lpo, Mpo, Ptgs2, Rag2, Tmod1, Tpo). The Aass (Alpha-aminoadipic semialdehyde synthase - mitochondrial) is a bifunctional enzyme that catalyzes the first two steps in the mammalian lysine degradation pathway ${ }^{19}$. It up-regulation may mean an adjustment of the respiratory chain to the conditions of hypoxia in intestinal tissue. The Epx and Tpo in turn are from a family of mammalian peroxidases, that includes Lpo and Mpo, and all then related to electron transporter activity, oxide reductase activity, peroxidase activity and response to oxidative stress. Among the genes over expressed draws our attention the Kif9 (Kinesin family member 9). The kinesin is a protein belonging to a class of motor proteins found in eukaryotic cells. It moves along microtubule cables powered by the hydrolysis of ATP. Their active movement supports several cellular functions including mitosis, meiosis and transport of cargo such as axonal transport. 
Most of then walk towards the plus end of a microtubule which, in most cells, entails transporting cargo from the centre of the cell towards the periphery ${ }^{21}$. The up-regulation of Kif9 can be taken as an attempt by cells to maintain their integrity of microtubules and further studies should consider this factor as a monitor of modulation or predictive biomarker on the effects of intestinal ischemia/reperfusion injury. Similarly over expressions of other catalases studied deserve further studies to take advantage of the capability of the findings.

Most of the oxygen consumed by aerobic organisms is reduced to water but a significant proportion of the oxygen molecules are converted to superoxide anion radicals. Chemicallyreactive molecules containing oxygen such as oxygen ions and peroxides are highly reactive due to the presence of unpaired valence shell electrons. A cascade of enzymes, some of them inside the mitochondria themselves, scavenges superoxide anions in order to protect cells from oxidative damage induced by reactive oxygen species (ROS). The yield of superoxide generation and subsequently ROS production depend mostly on oxygen concentration ${ }^{22}$.

Effects of ROS on cell metabolism have been well documented in different tissues and organs in a large number of species. These include not only roles in apoptosis but also positive effects such as the induction of host defense genes and mobilization of ion transport systems. This reactive oxygen species (ROS) form as a consequence of the normal metabolism of oxygen and play important roles in cell signaling. ROS levels can increase dramatically into a situation of hypoxia and is associated with increases in the expression of genes critical for tissue oxygen consumption $^{23}$. The present study found changes in the quantitative expression level of key genes of ROS. On the cluster of 16 genes involved with the ROS genes, nine $(56.3 \%)$ were significantly up-regulated. The up-regulation of IL22 and IL19 drew attention. Interleukin-22 is related as extracellular protein involved to acutephase of inflammatory response by a mechanism of cell-cell signaling, while interleukin-19 is also an extracellular protein related to cytokine activity and signal transduction of immune response $^{24}$. Our data suggest that the IR small bowel injury triggers a response in the production of proteins whose function is to promote an early inflammatory response and this signals a pathway that should be explored more carefully in future research.

The nicotinamide adenine dinucleotide phosphateoxidase (NADPH-oxidase) generates superoxide by transferring electrons from NADPH inside the cell across the membrane and coupling these to molecular oxygen to produce the superoxide. Under normal circumstances, the complex is latent in neutrophils and is activated during respiratory chain. It is well known the role of neutrophils adherence and the production of inflammatory substances during oxidative stress situations ${ }^{25}$. In the present research the gene expression of Nox1, Nox4, Noxa and Noxo1 were up-regulated. Does it show the attempt of small bowel tissue in to protect itself from ROS or should be a deleterious effect that worsening the IRI? Drug therapies or procedures of ischemic preconditioning can make contribution to the better understanding of how actually the mitochondrial respiratory chain acts on the phenomenon and how were the best options to reduce or eliminate their effects.

Considering now the gene expression related of 22 genes involved in the cluster of oxidative stress responsive metabolism, $19(86.3 \%)$ of them showed significant fold up-regulation. The highest over expression was due to genes Ucp3, Nudt15, Mpp4, Prnp, Ercc2 and Zmynd17. Ucp3 is member of the larger family of mitochondrial anion carrier proteins and facilitate the transfer of anions from the inner to the outer mitochondrial membrane and the return transfer of protons from the outer to the inner mitochondrial membrane. It also reduce the mitochondrial membrane potential in mammalian cells. This gene's protein product is postulated to protect mitochondria against lipid-induced oxidative stress $^{2,27}$. Nudt15 mediates the hydrolysis of some nucleoside diphosphate derivatives and in vitro is associated to preventing misincorporation of 8-oxo-dGTP into DNA thus preventing A:T to $\mathrm{C}: \mathrm{G}$ transversions. Its substrate specificity in vivo however remains unclear but may have a role in DNA synthesis and cell cycle progression thought the interaction with proliferating cell nuclear antigen (PCNA) ${ }^{28}$. The Prnp gene provides instructions for making a protein called the prion protein $(\mathrm{PrP})$, which is active in the brain and several other tissues. Although the precise function of PrP is unknown, it is probably involved in the transport of charged copper atoms (copper ions) into cells. Researchers have also proposed roles for PrP in cell signaling, cell protection, and the formation of synapses, which are the junctions between nerve cells (neurons) where cell-to-cell communication occurs ${ }^{29}$. Could it be that the up regulation is associated with the protecting of the myoenteric plexus? It is a path to be explored. Our results with this cluster point to a significant over expression of genes encoding the oxidative stress responsive metabolism, but they need more researches to prove and establish correlations between these findings and the possibility of interfering on them.

The transport of oxygen is related to the directed movement of oxygen into, out of or within a cell, by means of some agent such as a transporter or pore. Within the red blood cell the hemoglobin molecule is subjected to modulation mechanisms, 
which optimize its functional behavior to the specific physiological requirements. At the cellular level, these modulation mechanisms are utilized to perform a number of other functions that are not minor with respect to the basic function of oxygen transport ${ }^{30}$. A dynamic mathematic model of RBC metabolism, involving the $\mathrm{O}_{2}$ sensing mechanism of hemoglobin and the hypoxia-induced activation correlated with their release to predict temporal alterations in intracellular metabolites and cellular energetic in response to hypoxia ${ }^{31}$.

In present work from 12 genes involved in oxygen transporters metabolism, 11 (91.6\%) were up-regulated, but eight $(66.7 \%)$ of them were up-regulated than threefold, three $(25 \%)$ were up-regulated less than twofold and only one $(8.3 \%)$ was down-regulated. Hbq1 a member of the human alpha-globin gene family that involves five functional genes and two pseudo genes showed the highest expression among the oxygen transport genes investigated. Instead the predictive interactions of Hbq1 with the others four alpha globins, their expression in the different tissues and exactly function is until now unknown ${ }^{32}$. Myoglobin $(\mathrm{Mb})$ is an iron- and oxygen-binding protein found in the muscle tissue (mainly in the heart and skeletal muscle) of vertebrates in general and in almost all mammals. It is related to hemoglobin, which is the iron- and oxygen-binding protein in blood, specifically in the red blood cells. The only time myoglobin is found in the bloodstream is when it is released following muscle injury. It is an abnormal finding, and can be diagnostically relevant when found in blood $^{33}$. In the present research the gene was up-regulated. Recent studies suggest that NO can serve as an antioxidant of the high oxidizing ferryl myoglobin which has been proposed at least in part responsible for the oxidative damage caused by the reperfusion of ischemic tissues. The relationship between NO and myoglobin probably plays a role when NO was completely consumed and large amount of nitrite are still present ${ }^{34}$. A further research in our experimental model should try to establish the relationship between gene expression observed and the presence of myoglobin into the bloodstream. It would also be highly relevant to associate with such events of IRI to the intestinal smooth muscle. $\mathrm{Ngb}$ is a gene that encodes an oxygen-binding protein that is distantly related to members of the globin gene family. It is highly conserved among other vertebrates. It is expressed in the central and peripheral nervous system where it may be involved in increasing oxygen availability and providing protection under hypoxic/ischemic conditions. Neuroglobin (Ngb) and citoglobin $(\mathrm{CYgb})$ are two globins, whose functions are still a matter of debate. Its physiological role is unknown but, like hemoglobin, myoglobin, and cytoglobin/histoglobin, it may transport oxygen, detoxify reactive oxygen species, or serve as a hypoxia sensor. A potential role of detoxification of ROS is suggested mainly in neuronal tissue ${ }^{35}$. In the present work we observed a significantly up-regulation of $\mathrm{Ngb}$ and Cygb suggesting that the simultaneous study of the myenteric plexus should be a promise line of investigation. Fance is gene related to protect primary blood cells from cytotoxic and genotoxic effects of cross-linking agents in a specific illness (Fanconi anemia) but also exhibits functions in hematopoietic normal cells in addition to its role in the complex corrects the defect in Fanconi anemia complementation group $\mathrm{C}$ cells $^{36}$. Our data showed a significantly up-regulation $(+7.25)$ that could be related to attempt to protect the blood cells from ischemia damage.

To sum up, the RT-qPCR tool allowed an evaluation of a wide range of 84 genes correlated with oxidative stress in a model study of ischemia and reperfusion injury in the intestine of inbred mice. The results indicated a clear hyper-expression of genes that are known to be involved in antioxidant defense mechanism. The literature review did not show any other work involving this type of model or somewhat similar. This unprecedented study opens perspectives to a more detailed analysis for each gene family. The results obtained here on the gene expression of the oxidative stress could be compared with the effect of the different antioxidants drugs, scavengers of ROS, the procedures for ischemic preconditioning, hyperbaric oxygen, and other proceedings commonly used for relieve or abolish ischemia and reperfusion intestinal injury. The report also points to an ultimate and practical application study of the phenomena of ischemia and reperfusion with a chance of applicability on monitoring of clinical conditions such as those of intestinal transplantation.

\section{Conclusion}

The intestinal ischemia and reperfusion promote a global hyper-expression profile of six different clusters genes related to antioxidant defense and oxidative stress.

\section{References}

1. Carden DL, Granger DN. Pathophysiology of ischaemia-reperfusion injury. J Pathol. 2000;190:255-66.

2. Collard C, Gelman S. Pathophysiology, clinical manifestations, and prevention of ischemia-reperfusion injury. Anesthesiology. 2001;94:1133-8.

3. Yogaratnam JZ, Laden G, Guvendik L, Cowen M, Cale A, Griffin S. Hyperbaric oxygen: A novel technology for modulating myocardial ischemia-reperfusion via a single drug. Adv Ther. 2006;23(4):52833.

4. Tapuria N, Kumar Y, Habib MM, Amara MA, Seifalian AM, 
Davidson BR. Remote ischemic preconditioning: a novel protective method from ischemia reperfusion injury-A review. J Surg Res. 2008;150:304-30.

5. Kim CH, Choi H, Chun YS, Kim GT, Park JW, Kim MS. Hyperbaric oxygenation pretreatment induces catalase and reduces infarct size in ischemic rat myocardium. Pflugers Arch. 2001;442:519-25.

6. Oltean M, Zhu C, Mera S, Pullerits R, Mattsby-Baltzer I, Mölne J, Hallberg E, Blomgren K, Olausson M. Reduced liver injury and cytokine release after transplantation of preconditioned intestines. J Surg Res. 2009;154(1):30-7.

7. Bertoletto PR, José Carlos Chaves JC, Fagundes ATN, Simões RS, Oshima CTF, Simões MJ, Fagundes DJ. Effect of different periods of hyperbaric oxygen on ischemia-reperfusion injury of rat small bowel. Acta Cir Bras. 2008;23 (1):23-6.

8. Michiels C, Minet E, Mottet D, Raes M. Regulation of gene expression by oxygen: NF- $\mathrm{B}$ and HIF-1, two extremes. Free Rad Biol Med. 2002;33(9):1231-42.

9. Mandelker L. Introduction to oxidative stress and mitochondrial dysfunction. Vet Clin North Am Small Anim Pract. 2008;38:1-30.

10. Deepak SA, Kottapalli KR, Rakwal R, Oros G, Rangappa KS, Iwahashi H, Masuo Y, Agrawal GK. Real-Time PCR: revolutionizing detection and expression analysis of genes. Curr Genomics. 2007;8(4):234-51.

11. Pellegrini M, Marcotte EM, Thompson MJ, Eisenberg D, Yeates TO. Assigning protein functions by comparative genome analysis: protein phylogenetic profiles. Proc Natl Acad Sci USA. 1999;96(8):4285-8.

12. Flohé L, Toppo S, Cozza G, Ursini F. A Comparison of thiol peroxidase mechanisms. Antioxid Red Sig (on line). Available from http://www.liebertonline.com/doi/abs/10.1089/ars.2010.3397.

13. GNCPro Gene Network Central. GPx7and smooth muscle 213170־ᄀatGPX7. Graph for job ID: 61300719498. Available from http://www.gncpro.sabiosciences.com/gncpro/expression grapher.php?gene $=\mathrm{GPX} 7$

14. Pontell L, Sharma P, Rivera LR, Thacker M, Tan YH, Brock JA, Furness JB. Damaging effects of ischemia/reperfusion on intestinal muscle. Cell Tissue Res. 2011;343(2):411-9.

15. Taha MO, Miranda-Ferreira R, Fagundes AL, Fagundes DJ, Simões RS, Santos JM, Souza PD, Oliveira-Júnior IS, Marchini A, Gomes IT, Monteiro HP, Mendonça LO, Caricati-Neto A. Effects of L-nitroarginine methyl ester, an inhibitor of nitric oxide biosynthesis, on intestinal ischemia/reperfusion injury in rabbits. Transplant Proc. 2010;42(2):457-60.

16. Taha MO, Miranda-Ferreira R, Paez RP, Simões RS, Boin HC, Martins IA, Versage PF, Silva HF, Penzo LD, Fagundes AL, Oliveira I Jr, Caricati-Neto A, Monteiro HP. Role of L-arginine, a substrate of nitric oxide biosynthesis, on intestinal ischemia-reperfusion in rabbits. Transplant Proc. 2010;42(2):448-50.

17. Dietz KJ. Peroxiredoxins in plants and cyanobacteria. Antioxid Redox Signal. 2011;15(4):1129-59.

18. GNCPro Gene Network Central. GPx7 and smooth muscle 213170־־_atGPX7. Graph for job ID: 61300719498. Available in: http://gncpro.sabiosciences.com/gncpro/expression_grapher. php?gene=EHD2

19. Sacksteder KA, Biery BJ, Morrell JC, Goodman BK, Geisbrecht BV, Cox RP, Gould SJ, Geraghty MT. Identification of the a-aminoadipic semialdehyde synthase gene, which is defective in familial hyperlysinemia. Am J Hum Genet. 2000;66:1736-43.

20. Ishibashi $\mathrm{N}$, Weisbrot-LefkowitzM, Reuhl $\mathrm{K}$, Inouye $\mathrm{M}$, Mirochnitchenko O. Modulation of chemokine expression during ischemia/reperfusion in transgenic mice overproducing human glutathione peroxidases. J Immunol. 1999;163:5666-77.

21. Mayer F. Cytoskeletons in prokaryotes. Cell Biol Int. 2003;27:429-
38 .

22. Casteilla L, Rigoulet M, Pénicaud L. Mitochondrial ROS metabolism: modulation by uncoupling proteins. IUBMB Life. 2001;52(3-5):181-8.

23. Hall JR, Short CE, Petersen LH, Stacey J, Gamperl AK, Driedzic WR. Expression levels of genes associated with oxygen utilization, glucose transport and glucose phosphorylation in hypoxia exposed Atlantic cod (Gadus morhua). Comp Biochem Phys. 2009;(D4):12838.

24. Kuldo JM, Ogawara KI, Werner N, Ásgeirsdóttir SA, Kamps JAAM, Kok RJ, Molema G. Molecular pathways of endothelial cell activation for (targeted). pharmacological intervention of chronic inflammatory diseases. Curr Vasc Pharmacol. 2005;3:11-39.

25. Glantzounis GK, Salacinski HJ, Yang W, Davidson BR, Seifalian $\mathrm{AM}$. The contemporary role of antioxidant therapy in attenuating liver ischemia-reperfusion injury: a review. Liver Transplant. 2005;11(9):1031-47.

26. Sakamaki K, Kanda N, Ueda T, Aikawa E, Nagata S. The eosinophil peroxidase gene forms a cluster with the genes for myeloperoxidase and lactoperoxidase on human chromosome 17. Cytogenet Cell Genet. 2000;88( 3-4):246-8.

27. Protein UCP3. Available from http://www.nrresource.org/Pathways/ MR\%20Target\%20Genes/94837.html.

28. Ishibashi $\mathrm{T}$, Hayakawa $\mathrm{H}$, Ito R, Miyazawa M, Yamagata $\mathrm{Y}$, Sekiguchi M. Mammalian enzymes for preventing transcriptional errors caused by oxidative damage. Nucleic Acids Res. 2005; 33(12):3779-84.

29. Thumdee P, Ponsuksili S, Murani E, Nganvongpanit K, Gehrig B, Tesfaye D, Gilles M, Hoelker M, Jennen D, Griese J, Schellander $\mathrm{K}$, Wimmers K. Expression of the prion protein gene (PRNP) and cellular prion protein $(\mathrm{PrPc})$ in cattle and sheep fetuses and maternal tissues during pregnancy. Gene Expr. 2007;13(4-5):283-97.

30. De Rosa MC, Carelli Alinovi C, Galtieri A, Russo A, Giardina B. Allosteric properties of hemoglobin and the plasma membrane of the erythrocyte: new insights in gas transport and metabolic modulation. IUBMB Life. 2008;60(2):87-93.

31. Castagnola M, Messana I, Sanna MT, Giardina B. Oxygen-linked modulation of erythrocyte metabolism: state of the art. Blood Transfus. 2010;8(Suppl 3): s53-8.

32. Patrinos GP, Manoussos PK, Papadakis N. Molecular diagnosis of inherited disorders: lessons from hemoglobinopathies. Hum Mut. 2005;26(5):399-412.

33. Flögel U, Göecke A, Klotz L, Schrader J. Role of myoglobin in the antioxidant defense of the heart. FASEB J. 2004;18:1156-8.

34. Herold S, Rehmann FJ. Kinetic and mechanistic studies of the reactions of nitrogen monoxide and nitrite with ferryl myoglobin. J Biol Inorg Chem. 2001;6(5-6):543-55.

35. Nishi H, Inagi R, Kawada N,Yoshizato K, Mimura I, Fujita T, Nangaku M. Cytoglobin, a novel member of the globin family, protects kidney fibroblasts against oxidative stress under ischemic conditions Am J Pathol. 2011;178(1):128-39.

36. Pang Q, Christianson TA, Keeble W, Diaz J, Faulkner GR, Reifsteck C, Olson S, Bagby GC. The Fanconi anemia complementation group $\mathrm{C}$ gene product: structural evidence of multifunctionality. Blood. 2001;98:1392-401. 


\section{Acknowledgments}

To Operative Technique and Experimental Surgery Division, Department of Surgery and Molecular Gynecology Facilities, UNIFESP. The authors thank the biologist, Fellow PhD degree, Molecular Gynecology Postgraduate Program, UNIFESP, Marcos Azevedo Junior for gene expression technology and adviser support; Associate Professor, Department of Gynecology and Head of Molecular Gynecology Facilities, UNIFESP, Ismael Dale Cotrin Guerreiro da Silva for analysis of gene expression supports and Maria do Carmo Negrini Fagundes for assistance with translation and formatting of the article. Financial support was partially provided by Grande Dourados Federal University.

\section{Correspondence:}

Paulo Roberto Bertoletto

Rua João Rosa Góes, 1290

79825-070 Dourados - MS Brasil

Tel.: (55 67)3427-0321

bertoletto@terra.com.br

Received: June 12, 2012

Review: August 14, 2012

Accepted: September 17, 2012

Conflict of interest: none

Financial source: none

${ }^{1}$ Research performed at Experimental Surgery Department, Medical School, Federal University of Grande Dourados (UFGD), Dourados-MS, Brazil. Part of PhD thesis, Postgraduate Program in Interdisciplinary Surgical Sciences, São Paulo Federal University (UNIFESP). Tutor: Djalma José Fagundes. 